DOI: 10.34220/MAMSP_26-30

УДК 004: 629

ПРИМЕНЕНИЕ АЭРОСЕВА ДЛЯ ЛЕСОВОССТАНОВЛЕНИЯ

\author{
Д.Н. Демидов ${ }^{1}$ \\ ${ }^{1}$ ФГБОУ ВО «Воронежский государственный лесотехнический \\ университет имени Г.Ф. Морозова»
}

Ввиду наличия в лесном фонде РФ достаточного количества площадей, недоступных, непригодных или неэффективных для использования наземных средств механизации (вырубки, гари, полог леса, овражно-балочная сеть, склоны и др.), целесообразно проводить высев лесных семян с воздуха с использованием беспилотных авиационных систем.

Ключевые слова: аэросев; навигация, процесс, метод, лесовосстановление.

\title{
AERIAL SEEDING APPLICATION FOR REFORESTATION
}

\author{
D.N. Demidov ${ }^{1}$
}

${ }^{1}$ Voronezh State University of Forestry and Technologies named after G.F. Morozov

Due to the presence in the forest fund of the Russian Federation of a sufficient number of areas that are inaccessible, unsuitable or inefficient for the use of ground-based mechanization tools (felling, burning, forest canopy, ravine-beam network, slopes), it is advisable to sow forest seeds from the air using unmanned aircraft systems.

Keywords: aerial seeding, navigation, process, method, reforestation.

Несомненно, естественная регенерация может разработать более разумную и стабильную структуру экосистемы $[13,14]$ и является простым способом для восстановления растительности на труднодоступных площадях [15]. Например, в Китайской народной республике природные леса, произошедшие из семян при естественном возобновлении, доминируют и занимают по площади около 70 \% территории. Однако, в крупных и отдаленных районах, особенно в районах техногенных катастроф, где перелески встречаются довольно огра-

(С) Демидов Д.Н., 2021 
ниченно, процесс естественного возобновления и последующего развития лесных сукцессий может занять намного больше времени.

Направлением, тесно связанным с искусственным лесовосстановлением, является предпосевная обработка и хранение семян, а также их прямой высев в закрытый (лесосеменные центры) и открытый грунт. Однако в крупных и отдаленных районах (особенно в районах техногенных катастроф), на эродированных склонах (рисунок 1 [16]), где перелески встречаются довольно ограниченно, процесс естественного возобновления и последующего развития лесных сукцессий может занять намного больше времени $[5,6,10,11]$.

Ввиду наличия в лесном фонде РФ достаточного количества площадей, недоступных, непригодных или неэффективных для использования наземных средств механизации (вырубки, гари, полог леса, овражно-балочная сеть, склоны и др.), целесообразно проводить высев лесных семян с воздуха с использованием беспилотных авиационных систем. Разработка технологической основы создания лесов на труднодоступных площадях с помощью высева семян ведется учеными и естествоиспытателями в научном мире довольно давно. Существуют упоминания о ряде базовых технологических операций высева, датируемых 14 веком нашей эры. При этом многие сведения об операции комбинированного высева, включающей высев семян одного вида, смеси семян разных видов деревьев, или смесь семян деревьев и других видов растений, зачастую не содержат упоминания эффективности прямого высева.

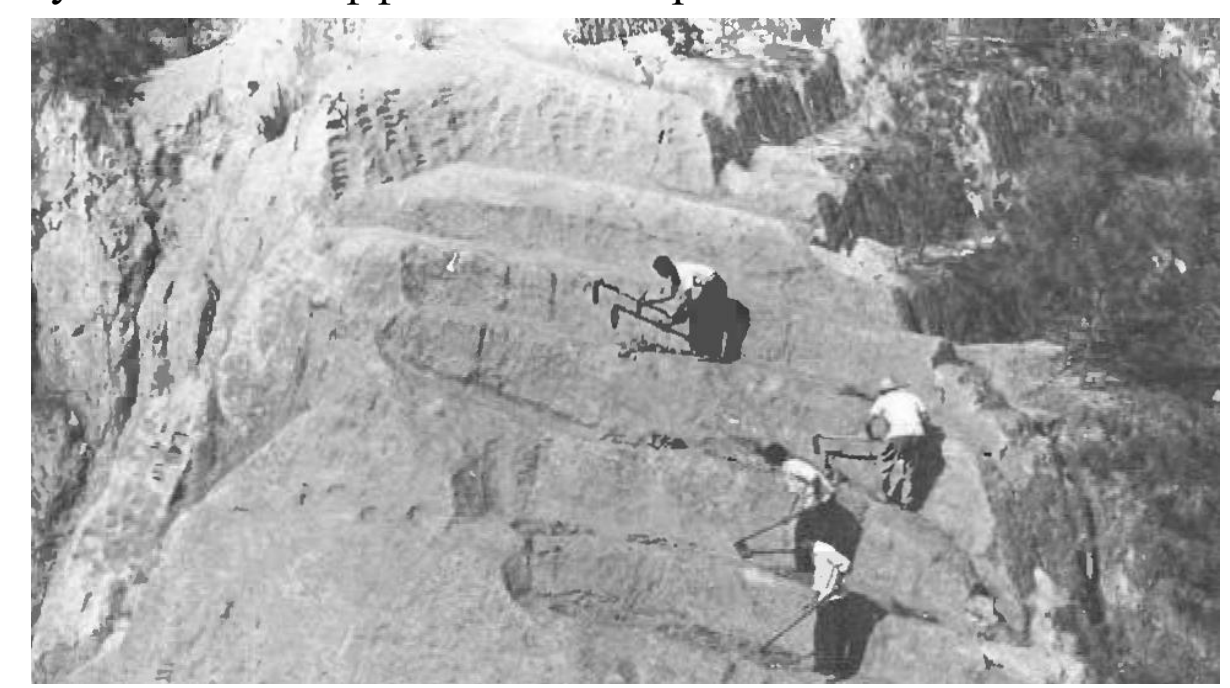

Рисунок 1 - Сохранение почв и искусственное лесовосстановление Pinus Elliotti на эродированных склонах в провинции Guangdong (КНP)

Андрей Андреевич Нартов (1737-1813) в статье «О посеве леса» (1765), наряду с делением лесных культур сосны и ели на лесотипологические группы по условиям местопроизрастания и качеству роста, предложил осуществлять 
высев леса: «У нас находятся три рода обыкновенных деревьев, а именно: ель, сосна и береза, кои легко на самой скудной и сухой земле в великом множестве вырастают. При посеянии сих деревьев должно примечать следующие три вещи, а именно: в какое время собирать семена, как и на какой земле их сеять надлежит». При этом он приводит для семян время сбора, время выхода из шишек, время хранения до высева, время высева, однако не упоминает как о существовании необходимости действий перед высевом (предпосевной обработки), так и последовательности, особенностей (технологии) самого высева.

Андрей Тимофеевич Болотов (1738-1833) в работе «Некоторые дальнейшие замечания о высеве лесов, могущие служить руководством для желающих заводить оные» (1781) дает ряд ценных практических рекомендаций по проведению высева семян на неудобиях, делая акцент на технологии, учитывающей геометрические и геоморфологические параметры восстанавливаемой площади.

Георгий Федорович Морозов в «Очерках по лесокультурному делу» констатирует, что посев имеет преимущество перед посадкой «а) при образовании дубового леса; б) в гористых, каменистых или сильно щебневых почвах, где посадка немыслима и где необходимо, чтобы корневая система приспособилась к неправильностям распределения мелкозема, трещинам среди скал».

James William Toumey, профессор лесной школы Йелльского университета (США), в труде «Seeding and planting: a manual for the guidance of forestry students, foresters, nurserymen, forest owners, and farmers» (1916) отмечал целесообразность прямого высева и особую роль отводил «тестированию лесных семян на жизнеспособность по внешним признакам» (Тoumey 1916), заложив прототип современной группы операций подготовки семян по спектрометрическим признакам.

Прямой высев представляет собой технологический процесс, с помощью которого производится восстановление агролесных ландшафтов путем высева семян деревьев вручную или механизировано непосредственно в их конечное положение произрастания [9]. Этот технологический процесс использовался реже по сравнению с посадкой, но практически во всем мире, включая Северную Америку [17] и Европу. Проблемы прямого высева, такие как хищничество мышей и птиц, выборочное прорастание и мощный рост сорняков, постепенно признавались учеными, что привело к практике высева семян на небольшие участки земли отдельно от конечного места посадки, где можно было контролировать хищничество и рост сорняков. Этот процесс в конечном итоге привел 
к развитию лесных питомников, а также к распространенной практике выращивания саженцев в питомнике перед высадкой в поле.

Особое внимание при использовании прямого высева обращалось на следующее [1-6]: прорастание семян деревьев происходит медленно, давая животным, птицам и насекомым время нанести потери; прорастание семян деревьев непредсказуемо, и даже лабораторно проверенные семена, которые способны прорастать при оптимальных условиях, часто не прорастают в полевых; относительно медленный рост сеянцев, полученных с помощью операций прямого высева, означает, что они конкурируют за скудные ресурсы, такие как свет, питательные вещества и влага, с другими быстрорастущими, однолетними и многолетними, видами. В последнее время теоретические преимущества прямого посева над посадкой, такие как более быстрое создание, более качественная древесина, более естественный внешний вид, снижение затрат на прополку и более низкая стоимость [7-12], дали возможность рассматривать данный технологический процесс применительно к лесовосстановлению труднодоступных площадей.

\section{Список литературы}

1. Новиков, А.И. Математическое обоснование технологии сепарирования лесных семян / А.И. Новиков // Моделирование систем и процессов. - 2018. T. 11, № 3. - C. 44-49.

2. Лавлинский, В.В. Применение математического описания действий для целенаправленных систем на основе методов нейронных сетей / В.В. Лавлинский, С.Н. Янышин // Моделирование систем и процессов. - 2017. - Т. 10, № 2. - С. 1723.

3. Котов, П.А. Модели технических систем и вопросы устойчивости в особенных случаях применительно к задачам энергомашиностроения / П.А. Котов // Моделирование систем и процессов. - 2017. - Т. 10, № 1. - С. 29-31.

4. Анализ проблем моделирования элементов КМОП БИС / В.К. Зольников, С.А. Евдокимова, А.В. Фомичев, В.Н. Чикин, А.В. Ачкасов, В.Ф. Зинченко // Моделирование систем и процессов. - 2018. - Т. 11, № 4. - С. 20-25.

5. Евдокимова, С.А. Анализ таксационной базы данных при работе с лесным электронным планшетом в ГИС // Моделирование систем и процессов. 2012. - № 2. - C. 36-39.

6. Свиридов, Л.Т. Исторический аспект проблемы сортирования лесных семян / Л.Т. Свиридов, А.И. Новиков // Лес в жизни восточных славян от 
Киевской Руси до наших дней : сб. науч. тр. ин-та леса НАН Беларуси. - Гомель : ИЛ НАН Беларуси, 2003. - Вып. 57. - С. 186-190.

7. Свиридов, Л.Т. Перспективные технические средства для обработки семян хвойных пород / Л.Т. Свиридов, Н.Д. Гомзяков, А.И. Новиков // Лесное хозяйство. - 2007. - № 2. - С. 44-46.

8. Драпалюк, М.В. Анализ операционных механизированных технологий сепарации семян при искусственном лесовосстановлении / М.В. Драпалюк, А.И. Новиков // Лесотехнический журнал. - 2018. - Т. 8, № 4. - С. 207-220.

9. Новиков, А.И. Дисковые сепараторы семян в лесохозяйственном производстве / А.И. Новиков - Воронеж, 2017. - 159 с.

10. Новиков, А.И. Экспресс-анализ лесных семян биофизическими методами / А.И. Новиков - Воронеж, 2018.- 128 с.

11. Novikov, A.I. Mechanization of coniferous seeds grading in Russia: a selected literature analysis / A.I. Novikov, B.T. Ersson, V.V Malyshev, E.P. Petrishchev, A.A. Ilunina // IOP Conference Series: Earth and Environmental Science - 2020. - T. 595. - Pp. 012060. - DOI: 10.1088/1755-1315/595/1/012060.

12. Bacherikov, I.V. Discrete seed feeder designing for mobile apparatus : early results for Pinus sylvestris L. Species / I.V. Bacherikov, A.I. Novikov, E.P. Petrishchev // Inventions. - 2021. - T. 6, № 1. - id14. - DOI: 10.3390/inventions6010014.

13. Tripathi, K.P. Species diversity and vegetation structure across various strata in natural and plantation forests in Katerniaghat Wildlife Sanctuary, north India / K.P. Tripathi, B. Singh // Trop. Ecol. - 2009. - Vol. 50. - Pp. 191-200.

14. Zhai, M. Concept for Vegetation Rehabilitation and Construction in the North-west Region of China / M. Zhai // J. Soil Water Conserv. - 2006. - Vol. 1, № 1. - P. 60-63.

15. Shono, K. Application of assisted natural regeneration to restore degraded tropical forestlands / K. Shono, E.A. Cadaweng, P.B. Durst // Restor. Ecol. - 2007. Vol. 15, № 4. - Pp. 620-626.

16. FAO. Forestry in China // FAO For. Pap. - 1982. - Vol. 35. - Pp. 1-307.

17. Novikov, A.I. Aerial seeding of forests in Russia: a selected literature analysis / A.I. Novikov, B.T. Ersson // IOP Conference Series: Earth and Environmental Science. International Jubilee Scientific and Practical Conference «Innovative Directions of Development of the Forestry Complex (FORESTRY2018)». - 2019. - Pp. 012051. - DOI: 10.1088/1755-1315/226/1/012051. 